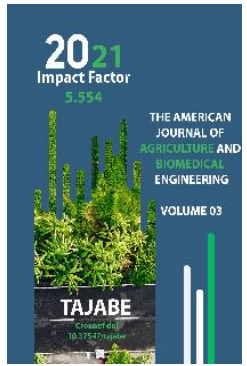

Journal Website: http://theamericanjour nals.com/index.php/taj abe

Copyright: Original content from this work may be used under the terms of the creative commons attributes 4.0 licence.

\section{Monocotyledonous Plants In The Flora Of Surkhandarya State Reserve}

lbragimov A.J.

TerDU Associate Professor, Uzbekistan

Qurbonova Z.

TerSU teacher, Uzbekistan

\title{
ABSTRACT
}

In present paper, the monocotyledonous plants of the Surkhan State Natural Reservoir which including 21 family, 80 genus and 208 species were analyzed.

\section{KEYWORDS}

Monocotyledonous, Floristic composition, altitude zone, Surkhandarya reserve.

\section{INTRODUCTION}

Surkhan State Reserve was established in 1986 and it is located on the eastern slope of the Kohitang Range, at an altitude of 850-3137 $\mathrm{m}$ above sea level. The total area is 24583 ha. Mainly mountain-forest ecosystems, rare animal and plant species are protected.

The first floristic composition of the Kohitang ridge was S.A. Cited by Nevsky [1]. His data mainly concerned the western slopes of the ridge, and based on herbarium materials collected from 588 species of plants, he noted that the floristic diversity of the Kohitang ridge consists of about 800 species. R.V. According to Kamelin [2], the flora of the Kohitang ridge is no less than 1,000 species. The author has recorded more than 860 species of plants for the western slope of the ridge alone.

F.O. Hasanov [3] listed 269 genus and 578 species of plants belonging to 55 families in the trees and shrubs of the Kohitang ridge. 
During the floristic research carried out in the reserve area, the species composition of monocotyledonous plants was determined. According to the results obtained, the monocotyledonous plants in the flora of the reserve consisted of 21 families, 80 genera and 208 species (Table 1 ).

Table 1

Floristic composition of monocotyledonous plants in Surkhandarya reserve

\begin{tabular}{|c|c|c|c|}
\hline $\mathrm{T} / \mathrm{p}$ & Families & Genus's & Number of species \\
\hline \multirow[t]{20}{*}{1} & \multirow[t]{20}{*}{ Poaceae } & Erianthus & 1 \\
\hline & & Botriochloa & 1 \\
\hline & & Sorghum & 1 \\
\hline & & Brachiaria & 1 \\
\hline & & Echinochloa & 1 \\
\hline & & Setaria & 1 \\
\hline & & Phalaris & 1 \\
\hline & & Achnatherum & 2 \\
\hline & & Stipa & 5 \\
\hline & & Piptatherum & 2 \\
\hline & & Milium & 1 \\
\hline & & Crypsis & 1 \\
\hline & & Phleum & 2 \\
\hline & & Alopecurus & 1 \\
\hline & & Polypogon & 3 \\
\hline & & Agrostis & 1 \\
\hline & & Calamagrostis & 2 \\
\hline & & Avena & 2 \\
\hline & & Cynodon & 1 \\
\hline & & Enneapogon & 1 \\
\hline
\end{tabular}


The American Journal of Agriculture and Boimedical Engineering (ISSN - 2689-1018)

IMPACT FACTOR

Published: June 30, 2021| Pages: 100-106

2021: $5 \cdot 554$

Doi: https://doi.org/10.37547/tajabe/Volume03Issueo6-14

OCLC - 1121105746

\begin{tabular}{|c|c|c|c|}
\hline & & Phragmites & 1 \\
\hline & & Eragrostis & 3 \\
\hline & & Melica & 3 \\
\hline & & Aeluropus & 3 \\
\hline & & Poa & 13 \\
\hline & & Colpodium & 1 \\
\hline & & Glyceria & 1 \\
\hline & & Puccinellia & 1 \\
\hline & & Secale & 1 \\
\hline & & Festuca & 3 \\
\hline & & Nardurus & 1 \\
\hline & & Vulpia & 3 \\
\hline & & Bromus & 11 \\
\hline & & Boissiera & 1 \\
\hline & & Trachynia & 1 \\
\hline & & Lolium & 2 \\
\hline & & Henrardia & 1 \\
\hline & & Agropyron & 4 \\
\hline & & Eremopyrum & 2 \\
\hline & & Aegilops & 4 \\
\hline & & Heteranthelium & 1 \\
\hline & & Taeniatherum & 1 \\
\hline & & Hordeum & 4 \\
\hline & & Elymus & 1 \\
\hline 2. & Asphodelaceae & Eremurus & 10 \\
\hline 3 & Alliaceae & Allium & 29 \\
\hline
\end{tabular}


The American Journal of Agriculture and Boimedical Engineering (ISSN - 2689-1018)

IMPACT FACTOR

Published: June 30, 2021| Pages: 100-106

Doi: https://doi.org/10.37547/tajabe/Volume03Issueo6-14

\begin{tabular}{|c|c|c|c|}
\hline \multirow[t]{7}{*}{4} & \multirow[t]{7}{*}{ Liliaceae } & Merendera & 1 \\
\hline & & Colchicum & 2 \\
\hline & & Gagea & 11 \\
\hline & & Rhinopetalum & 1 \\
\hline & & Fritillaria & 1 \\
\hline & & Tulipa & 7 \\
\hline & & Bellevalia & 2 \\
\hline \multirow[t]{5}{*}{5} & \multirow[t]{5}{*}{ Iridaceae } & Crocus & 1 \\
\hline & & Iris & 4 \\
\hline & & Juno & 5 \\
\hline & & Iridodictyum & 1 \\
\hline & & Gladiolus & 1 \\
\hline \multirow[t]{5}{*}{6} & \multirow[t]{5}{*}{ Cyperaceae } & Scirpus & 1 \\
\hline & & Bolboschoenus & 1 \\
\hline & & Cyperus & 3 \\
\hline & & Juncellus & 1 \\
\hline & & Carex & 4 \\
\hline 7 & Juncaceae & Juncus & 5 \\
\hline 8 & Typhaceae & Typha & 1 \\
\hline 9 & Potomogetonaceae & Potomogeton & 1 \\
\hline \multirow[t]{2}{*}{10} & \multirow[t]{2}{*}{ Araceae } & Arum & 1 \\
\hline & & Eminium & 1 \\
\hline 11 & Amarillidaceae & Ungernia & 1 \\
\hline 12 & Ixiolirionaceae & Ixiolirion & 1 \\
\hline \multirow[t]{2}{*}{13} & \multirow[t]{2}{*}{ Orchidaceae } & Epipactis & $\overline{1}$ \\
\hline & & Orchis & 1 \\
\hline
\end{tabular}


The American Journal of Agriculture and Boimedical Engineering (ISSN - 2689-1018)

Published: June 30, 2021| Pages: 100-106

Doi: https://doi.org/10.37547/tajabe/Volume03Issueo6-14

\begin{tabular}{|c|c|c|c|}
\hline 14 & Butomaceae & Butomus & 2 \\
\hline 15 & Alismataceae & Alisma & 1 \\
\hline 16 & Juncaginaceae & Triglochin & 2 \\
\hline 17 & Hyacintaceae & Muscari & 2 \\
\hline 18 & Asparagaceae & Asparagus & 1 \\
\hline 19 & Convallariaceae & Polygonatum & 2 \\
\hline 20 & Eriocaulaceae & Eriocaulon & 208 \\
\hline 21 & Lemnaceae & Lemna & 2 \\
\hline
\end{tabular}

The polymorphic families of monocotyledons in the flora of the reserve include Poaceae, Alliaceae, Liliaceae, Iridaceae, Cyperaceae, Asphodelaceae, and Juncaceae. This list includes families with more than 5 species. From this list, Alliaceae is a member of the polymorphic families of the general flora of the Poaceae reserve. These families make up to $61 \%$ of the reserves. There are 6 families with 2 and 3 species and 8 families with a single species. Polymorphic families include Allium, Poa, Gagea, Bromus, Eremurus, Tulipa, Stipa, Juno, and Juncus (Table 2). They make up to $46.1 \%$ of the total monocotyledons. The top five categories themselves include 74 species.

Table 2

\section{Monocotyledonous plants in the flora of Surkhandarya reserve \\ Polymorphic families and Genus's}

\begin{tabular}{|c|c|c|c|c|c|}
\hline \multirow{2}{*}{ T/p } & Families & \multicolumn{2}{|c|}{ Number } & \multirow{2}{*}{$\begin{array}{c}\text { Polymorphic } \\
\text { Genus's }\end{array}$} & $\begin{array}{c}\text { Number of } \\
\text { species }\end{array}$ \\
\cline { 3 - 4 } & Genus & species & 98 & Allium & 29 \\
\hline 1 & Poaceae & 44 & 29 & Poa & 13 \\
3 & Alliaceae & 1 & 25 & Gagea & 11 \\
4 & Liliaceae & 7 & 12 & Bromus & 11 \\
\hline
\end{tabular}




\begin{tabular}{|c|c|c|c|c|c|}
\hline 5 & Cyperaceae & 5 & 10 & Eremurus & 10 \\
6 & Asphodelaceae & 1 & 9 & Tulipa & 7 \\
7 & Juncaceae & 1 & 5 & Stipa & 5 \\
8 & & & Juno & 5 \\
9 & & & Juncus & 5 \\
& & & 188 & & 96 \\
\hline
\end{tabular}

Distribution of plants across altitude zones Q.Z. Zokirov [4] classification (Table 3). Surkhandarya Nature Reserve starts mainly in the Adir region. The majority of monocotyledonous plant species occur in the mountainous region (143 species, 68.7\%) and (122, 58.6\%) the Adir region. Pastures occupy

Table 3 small areas in the reserve area. Because the unique geomorphological structure of the ridge, extremely steep cliffs and the rocks prevent the spread of vegetation here. Therefore, monocotyledonous plants (16 species, $7.8 \%$ ) are rare in the pasture region.

\section{Distribution of monocotyledonous plants in Surkhandarya reserve, along altitude zone (according to Q.Z. Zokirov, 1955).}

\begin{tabular}{|c|c|c|c|}
\hline T/p & Height zones & Number of species & According\% \\
\hline 1. & Adir (700-1100 m) & 122 & 58.6 \\
2. & Mountain (1100-2600 m) & 143 & 68.7 \\
3. & Pasture (2600-3137 m) & 16 & 7.8 \\
4. & Adir Mountain & 60 & 28.8 \\
5. & Mountain-pasture & 7 & 3.3 \\
6 & Adir-mountain-pasture & 3 & 3 \\
\hline
\end{tabular}

In summary, the flora of the Surkhandarya reserve includes 208 species of monocotyledonous plants. Their initial analysis shows that this flora corresponds to the taxonomic spectrum of monocotyledons in the mountainous flora of Central Asia. Its distinctive features are the abundance of species of the genus Eremurus (10), the fact that the flora of the pasture region is characterized by few species.

\section{REFERENCES}

1. Nevskiy S.A. Materials to the flora of Kugitangtau and ego predgoriy. $\mathrm{V}$ sb. 
"Flora and systematics of higher plants". M., 1937, pp. 199-343.

2. Kamelin R.V. Floragenitecheskiy analiz estestvennoy gornoy flora Sredney Azii. Leningrad. Nauka.1973. st-353.

3. Khasanov F.O. Xerofilnaya drevesnokustarnikovaya rastitelnost Kugitangtau. Autoref. dis ... na soiskanie uchen. step. kand. biol. science. Tashkent, 1987.S. 230.

4. Zokirov K.Z. Flora and vegetation basseyna r. Zarafshan. Tashkent: AN UzSSR, 1955. p. 207. 